\title{
Pump It Up and Zig Zag Run Training Improve Children Agility Age 7-8 Years Old
}

\author{
Kurniani Fatma Hardini*, Gadis Meinar Sari, dan Choesnan Effendi \\ Universitas Airlangga, Surabaya, Indonesia \\ 16dini@gmail.com
}

\begin{abstract}
Recommended exercises that involve large muscles with a semi active game combined with singing or dancing that could increase the agility of children aged 7-8 years. This study aims to determine the effect of Pump It Up and Zig Zag Run exercises on agility in children aged 7-8 years. This study used experimental research, with a Randomized Pre and Post Test Group Design. This study consisted of 3 groups: the Pump It Up group, the Zig Zag Run game group, and the Shuttle Run game control group with a sample of each group of 10. The Agility Illionis Test was chosen as the agility test instrument. The exercise was done three days a week for four weeks. Anova test results showed that there was a significant effect of Pump It Up and Zig Zag Run exercises on agility with indigo $p$ $<0.05$, and LSD test showed there were differences in Pump It Up with Ziz Zag Run, there were differences in Pump It Up and Zig Zag Run with indigo $p<0.05$. The conclusion of this research was that Pump It Up and Zig Zag Run exercises increase agility.
\end{abstract}

Keywords: Pump It Up, Zig Zag Run, Shuttle Run, Agility. 


\section{STRADA Jurnal Ilmiah Kesehatan}

DOI: $10.30994 /$ sjik.v9i1.268

ISSN: 2252-3847 (print); 2614-350X (online)

Vol.9 No.1. May 2020. Page.54-59

\section{INTRODUCTION}

In Indonesia $57.3 \%$ of Indonesian children are categorized as inactive and in front of the TV / computer / PS $\geq 2$ hours per day (Heryudarini et al., 2013), this is in accordance with the research of O'loughlin et al. (2012) that more children boys play than girls, because girls prefer to watch television $\geq 2$ hours a day so girls tend to have little physical activity and easily have complaints of weight (overweigth / obesity). In the age group of primary school children (SD) who have an inactive lifestyle has a percentage of $67 \%$ (Burhaein, 2017). Based on the foregoing, physical activity is very important for overall growth and development in children (Stork and Sanders, 2008). This is a serious concern.

The existing technology means that children will tend to sit sweetly enjoying the facilities that are already available. This will cause children's activities to be reduced, causing gross motor development to slow down and will have more progressive impacts in the future such as growth and growth disorders, fat accumulation, and so on (Riyanto, 2017). Characteristics and principles of child growth and development according to the age range in elementary school children (SD) where the age period of 7-8 years including exercises involving large muscles (arms, legs, abdomen, back) with a semi active game combined with singing or dancing that sharpens strength, balance and agility.

To achieve the agility and balance of children aged 6-12 years needed stimulation that is adapted to the world of children, namely with games that are interesting for children (Yosinta, et al., 2016). Games using technology called exergaming. Exergaming offers an alternative to do even increase physical activity both children who are interesting to play and increasingly like to do physical activities with technology. Most exergaming studies are clinical based and measure energy expenditure during exergaming or exergame play. Exergame games consist of rhythmic dancing games (Pump It Up, Dance Dance Revolution, etc.), virtual bycicles, balance board stimulators, and sports simulators (O'Loughlin et al., 2012).

Pump It Up or PIU is a music video game series, which is played by stepping on a dance pad with five bottom panels: top-left, top-right, left-bottom, right-bottom and center or middle panel (Hans, 2010). Pump it up in the speed category can be classified as a form of exercise according to a study conducted by Widiarista (2015) where 14 respondents who regularly pumped a category of speed with $4 \mathrm{x}$ a week to 2 hours / week found that having physical strength was compared to 20 respondents who do not routinely do. In addition to the PIU game, to improve agility and balance can be given Zig Zag Run Training which is an exercise that is carried out by running around the cone with a specified duration of time (Wiadnyana, 2015). According to research conducted by Gutomo (2007) Zig Zag Run exercises and Carioca exercises are effectively used to increase the agility of beginner badminton players by being given exercise 3 times a week for 4 weeks, but regarding Pump It Up and Zig Zag Run exercises it is still unclear. Based on the description above, it is necessary to research the effect of Pump It Up and Zig Zag Run exercises on agility and balance in children aged 7-8 years.

\section{METHODS}

This type of research that will be used in this study is an experimental study, with a randomized study design Pre and Post Test Group Design. This study consisted of 3 groups, namely the 1 PIU game treatment group, the Zig Zag Run 2 game treatment group, and the Shuttle Run control group with a sample of 10 groups each obtained from the 1997 Lameshow formula. Formation of the group was carried out after the questionnaire (CPAQ) was given. to classify and proceed with lottery. The duration of the exercise is 12 
minutes with the frequency of exercise 3 times a week for 4 weeks. Agility is measured using the Agility Illionis Test.

\section{RESULTS}

Descriptive characteristics through descriptive statistical tests based on the minimum, maximum, average and standard deviation values of the control variables are presented in tabular form as follows:

Table 1 Characteristics of control variables

\begin{tabular}{|c|c|c|c|c|}
\hline Group & $\begin{array}{l}\text { Variabel } \\
\end{array}$ & Min & Maks & Mean \pm SD \\
\hline \multirow[t]{5}{*}{ Pump It Up (K1) } & Age (year) & 6,9 & 7,6 & $7,19 \pm 0,233$ \\
\hline & Weight $(\mathrm{kg})$ & 19 & 22 & $20,40 \pm 1,17$ \\
\hline & Height $(\mathrm{cm})$ & 118 & 122 & $119,90 \pm 1,37$ \\
\hline & Body Mass Index $\left(\mathrm{kg} / \mathrm{m}^{2}\right)$ & 13,19 & 15,08 & $14,19 \pm 0,71$ \\
\hline & Limb Lenght $(\mathrm{cm})$ & 50 & 55 & $52,60 \pm 1,84$ \\
\hline \multirow[t]{5}{*}{ Zigzag Run (K2) } & Age (year) & 6,8 & 7,7 & $7,22 \pm 0,25$ \\
\hline & Weight $(\mathrm{kg})$ & 18 & 22 & $20,20 \pm 1,23$ \\
\hline & Height $(\mathrm{cm})$ & 118 & 121 & $119,90 \pm 1,10$ \\
\hline & Body Mass Index $\left(\mathrm{kg} / \mathrm{m}^{2}\right)$ & 12,71 & 15,08 & $14,05 \pm 0,78$ \\
\hline & Limb Lenght $(\mathrm{cm})$ & 50 & 55 & $52,20 \pm 2,10$ \\
\hline \multirow{5}{*}{$\begin{array}{c}\text { Shuttle Run } \\
\text { (K3) }\end{array}$} & Age (year) & 6,9 & 7,9 & $7,46 \pm 0,32$ \\
\hline & Weight $(\mathrm{kg})$ & 19 & 23 & $20,60 \pm 1,26$ \\
\hline & Height $(\mathrm{cm})$ & 118 & 122 & $129,30 \pm 1,34$ \\
\hline & Body Mass Index $\left(\mathrm{kg} / \mathrm{m}^{2}\right)$ & 13,19 & 15,71 & $14,28 \pm 0,87$ \\
\hline & Limb Lenght $(\mathrm{cm})$ & 50 & 54 & $52,10 \pm 1,67$ \\
\hline
\end{tabular}

Based on table 1 shows the characteristics of the Pump It Up and Zigzag Run treatment groups, and the Shuttle Run control group showed almost the same value, so it can be said that the study sample has characteristics that are not much different. The agility test presents the average, normality, homogeneity, and anova in tabular form as follows:

Table 2: Test the Effect of Agility

\begin{tabular}{cccccc}
\hline Group & $\mathrm{n}$ & Mean $\pm \mathrm{SD}$ & $\begin{array}{c}\mathrm{P} \\
\text { Normalitas }\end{array}$ & $\begin{array}{c}\mathrm{p} \\
\text { Homogenitas }\end{array}$ & $\begin{array}{c}\mathrm{p} \\
\text { Anova }\end{array}$ \\
\hline K1 & 10 & $12,70 \pm 1,34$ & 0,47 & & \\
K2 & 10 & $10,70 \pm 1,06$ & 0,11 & 0,46 & 0,000 \\
K3 & 10 & $10,40 \pm 0,97$ & 0,24 & & \\
\hline
\end{tabular}

Information:

K1: Pump It Up treatment group

K2: Zigzag Run treatment group

K3: Shuttle Run control group 


\section{STRADA Jurnal Ilmiah Kesehatan}

DOI: $10.30994 /$ sjik.v9i1.268

ISSN: 2252-3847 (print); 2614-350X (online)

Vol.9 No.1. May 2020. Page.54-59

Based on table 2 shows that there is a significant influence on pump it up, zigzag run and control (shuttle run) on agility.

Table 3 LSD Agility Test

\begin{tabular}{cccc}
\hline Group & K1 & K2 & K3 \\
\hline K1 & - & $0,001^{*}$ & $0,00^{*}$ \\
\hline K2 & $0,001^{*}$ & - & 0,558 \\
\hline K3 & $0,000^{*}$ & 0,558 & - \\
\hline
\end{tabular}

Information:

*: Significant value

K1: Pump It Up treatment group

K2: Zigzag Run control group

K3: Shuttle Run control group

Based on LSD test table 2 shows that there was a significant difference between the pump it up (K1) treatment group with the zigzag run (K2) treatment group and the pump it up (K1) treatment group with the shuttle run control group (K3). However, the zigzag run (K2) and shuttle run (K3) control groups showed that there were no significant differences.

\section{DISCUSSION}

Based on ANOVA test table 2 which shows that there is a significant influence on Pump It Up and Zig Zag Run exercises on agility $(\mathrm{p}<0.05)$. This shows that Pump It Up and Zig Zag Run exercises increase agility time. The research which is almost the same as this research is a study conducted by Hardini (2015) that there is a significant relationship between pump it up with agility, and research by Gutomo (2012) shows that zig zag run is one type of exercise to improve agility. Pump It Up and Zig Zag Run exercises performed with a frequency of 3 times a week can cause changes in the motor unit recruitment system. Effect of Pump It Up and Zig Zag Run exercises on increasing agility due to changes in the recruitment system of the motor unit which is part of a muscular organ consisting of one efferent neuron and several muscle fibers that are innervated. The motor unit can be activated and activated, adjusting the activity received by the muscles known as type 1 muscle fibers and type II muscle fibers. Pump It Up and Zig Zag Run exercises consist of fast and powerful movements, involving type II muscle fiber motor units. Routine exercise will increase activation in motor units, so that motor units become easier and faster to activate. The more motor units involved when making movements, the greater the speed and explosive power the muscles produce. This has a positive correlation with increasing agility because agility is closely related to the two elements (Poomsalood \& Pakulanon, 2015). Besides that, pump it up and zig zag run exercises are special exercises to improve children's agility. This is because the exercise will involve the ability to change body position or body movements quickly without losing balance or awareness of orientation to body position is agility (Imranfik, 2012). Agility plays a special role in physical mobility. Training that involves components of speed and flexibility has certainly included agility (Sukadiyanto, 2005). It was concluded that an agile child is a child who has the ability to change the direction and position of the body quickly and precisely when he is moving, without losing balance and awareness of body position (Ismaryati, 2008).

Based on LSD test table 3, it shows that there is a significant difference between the Pump It Up (K1) group and the zig zag run (K2) group and there is a significant difference in the pump it up (K1) group with the shuttle Run (K3) control group towards agility with $\mathrm{p}$ $<0.05$. In addition, based on tebel 2, the Pump it up (K1) treatment group showed a higher 


\section{STRADA Jurnal Ilmiah Kesehatan}

DOI: $10.30994 /$ sjik.v9i1.268

ISSN: 2252-3847 (print); 2614-350X (online)

Vol.9 No.1. May 2020. Page.54-59

mean value than the zig zag run treatment group and the shuttle run control group. Based on these results, the Pump It Up exercise further increases agility, possibly because the Pump It up exercise provides a series of structured movements that adjust the rhythm and tempo of each song. This is almost the same as research conducted by Hardini (2015) that there is a significant relationship between pump it up with agility.

Pump it up is a combination of movements accompanied by music, where the faster the rhythm and tempo of the song, the faster the movement of the legs to press the pad bar to adjust the visual image of the arrows. According to Rad \& Hafezi (2013) music can improve psychological states when practicing and creating positive ideas. This will contribute to motivation and resistance to psychological fatigue, thereby increasing performance and learning skills so as to affect agility. Besides that Pump It Up exercises affect the agility of children is likely due to pump it up training in accordance with the needs of children. According to Widhianawati (2011) motion and song activities are very closely attached and cannot be separated, especially in providing learning to children, because motion and song learning is an activity in playing while learning and learning while playing, so that children can be happy in doing so.

Pump It up exercises are also able to stimulate aerobic and anaerobic abilities. This is in line with Hardini's (2015) presentation that playing Pump It Up is able to stimulate aerobic and anaerobic abilities by involving eccentric and isotonic contractions of various muscle groups that have an impact on muscle strength, speed, and agility as well. Individuals with good muscle strength coupled with good speed and coordination of movement will be able to move swiftly to change direction quickly without losing balance. Therefore Pump It Up exercises can increase agility.

Pump It Up training may affect agility probably also because Pump It Up training causes neuromusculoskeletal adaptation. Pump It Up Training requires concentration and coordination of movements which are also accompanied by speed with jumping movements so as to provide impulses for neuromusculoskeletal adaptation. The impact will increase intermuscular coordination so that it will affect the increase in agility (Hardini, 2015).

\section{CONCLUSIONS AND RECOMMENDATIONS}

The conclusion of this research was that Pump It Up and Zig Zag Run exercises increase agility. The biggest increase was in Pump It Up. Henceforth, research could be conducted with research subjects aged above or below 7-8 years.

\section{REFERENCES}

Burhaein, Erick. 2017. Indonesian Journal of Primary Education. Aktivitas Fisik Olahraga untuk Pertumbuhan dan Perkembangan Siswa SD. Vol 1 No 1 (2017) 51-58.

Gutomo, Bayu Sigit. 2012. Perbandingan Efektifitas Latihan Zig-Zag Run Dengan Carioca Exercise Untuk Meningkatkan Agility Pada Pemain Bulutangkis Pemula. Jurnal UEU.

Hans, Steven. 2010. https://sites.google.com/site/piuwestborneo/PiuWestBorneo.

Hardini, Kurniani Fatma. 2015. Hubungan Pump It Up terhadap Kelincahan Tungkai Bawah

Pada Remaja. Fakultas Ilmu Kesehatan: Skripsi. 
Imranfik. 2012. Pengukuran Kelincahan. 7 Juli 2012. Available fro: URL: http://Imranfik.blogspot.com/2012/07/Pengukuran-Kelincahan.html.

Ismariyati. 2008. Peningkatan Kelincahan Atlet Melalui Penggunaan Metode Kombinasi Latihan Sirkuit-Plyometrik dan Berat Badan. Paedagogia. Jilid 11. No.1. Februari 2008. 74-89.

O'loughlin, et al. 2012. Prevalence and Correlates of Exergaming in Youth. DOI:10.1542/peds.2012-0391 originally published online october 1, 2012.

Poomslood \& Pakulanon. 2015. Effect of 4-week Plyometric Trainingon Speed, Agility, And Leg Muscle Power In Male University Basket Ball Players: A Pilot Study. Kasetsart J.(Soc.Sci) 36: 1-9.

Rad, L.S. \& Hafezi, F. 2013. The Effect of Motivational Music During Exercise on The Performance of Elite Female Swimmers. European Journal of Experimental

Biology, 3(3): 106-110.

Stork, Steve dan Sanders, Stephen W. (2008). Physical Education in Early Childhood. The Elementary School Journal, Vol. 108, No. 3 (January 2008), pp. 197-206).

Sukadiyanto. 2005. Pengantar Teori dan Melatih Fisik. Yogyakarta: FIK Universitas Negeri Yogyakarta.

Wiadnyana, I Gusti Ngurah Sastra dkk. 2015. Pengaruh Pelatihan Zig Zag Run Terhadap Kecepatan Dan Kelincahan. e- journal jurnal IKOR Universitas Pendidikan Ganesha Jurusan Ilmu Keolahragaan Volume II.

Widhianawati, Nana. 2011. Pengaruh Pembelajaran Gerak dan Lagu Dalam Meningkatkan Kecerdasan Musikal dan Kecerdasan Kinestetik Anak Usia Dini. Edisi Khusus, 2(2011): 220-228.

Widiarista, Ayu Shalekha. 2015. Perbedaan Status Gizi dan Ketahanan Fisik Berdasarkan Tingkat Kerutinan Bermain Pump pada Remaja di komunita "A” Kota Semarang.

Jurnal Kesehatan Masyarakat (e-Journal) Volume 3, Nomor 1, Januari 2015 (ISSN: 2356 3346).

Yosinta, Septi Islinia., dkk. 2016. Jurnal Ilmiah Potensia. Vol. 1 (1), 56-60 